\title{
Spatial and temporal variation in crop diversity in agroforestry homegardens of southern Ethiopia
}

\author{
Tesfaye Abebe $\cdot$ K. F. Wiersum $\cdot$ F. Bongers
}

Received: 18 February 2009/Accepted: 4 July 2009/Published online: 31 July 2009

(C) The Author(s) 2009. This article is published with open access at Springerlink.com

\begin{abstract}
A key assumption in many homegarden studies is that homegardens are ecologically and socio-economically sustainable due to their species diversity. The precise relation between diversity and sustainability is still heavily debated, however. A basic question is how diversity in homegardens can best be characterized in view of the various dimensions of species diversity and their variation in time and space. This paper assesses different types of species diversity in the homegardens of Sidama region of southern Ethiopia. In a survey of crop species in 144 homegardens a total of 78 cultivated crop species (excluding trees) belonging to 10 functional groups were recorded; there were on average 16 crop species and 8 functional groups per farm. Within homegardens, plots differ in species composition and crop diversity. Four types of homegarden systems are distinguished differing in both type and area-share of
\end{abstract}

T. Abebe

College of Agriculture, Hawassa University, Awassa, Ethiopia

K. F. Wiersum ( $\bowtie)$

Forest and Nature Conservation Policy Group,

Wageningen University and Research Centre,

P.O. Box 47, 6700 AA Wageningen, The Netherlands

e-mail: freerk.wiersum@wur.nl

\section{F. Bongers}

Centre for Ecosystem Studies, Wageningen University and Research Centre, P.O. Box 47, 6700 AA Wageningen, The Netherlands dominant species, relative orientation at subsistence or cash production and overall crop diversity. The gradual replacement of enset by maize and of coffee by more financially attractive cash crops khat and pineapple causes a decrease in overall crop diversity. Our data demonstrate that it is incorrect to consider homegardens as generic systems with a uniform distribution of species diversity: important within and between homegarden variation exists. Ecological and socio-economic sustainability is not just related to species diversity per se, but rather to more specific features such as presence of keystone species and diversity in functional species groups. Socioeconomic sustainability in terms of adjustment to socio-economic change implies dynamics in species diversity.

Keywords Homegarden dynamics . Functional groups - Keystone species · Enset/coffee gardens - Species diversity

\section{Introduction}

Homegarden agroforestry systems in the tropics are known for their structural complexity and diversity in crop and other plant species (Kumar and Nair 2006). The cultivation of different crops in homegardens is regarded as a strategy of farmers to diversify their subsistence and cash needs. Diversification also helps to stabilize yield and income in cases of incidences of 
disease and pests, and market price fluctuations. Although the positive impacts of crop diversity on homegarden sustainability have been widely discussed (Fernandes and Nair 1986; Torquebiau 1992), the precise relation between diversity and sustainability is still in open debate (Kumar and Nair 2004). A basic question is how diversity in homegardens can best be characterized. Normally, diversity is expressed as the average number of species per homegarden in a specific region. Currently, increasing attention is given to the diverse nature of species diversity and their variation in time and space. For instance, ecologists differentiate between alpha (the diversity in a particular area or ecosystem), beta (the change of species diversity between ecosystems) and gamma (the overall species diversity for the different ecosystems within a region) (Magurran 1988; Huston 1994). In homegarden studies it has been noted that both within and between variation in diversity may exist. Relatively little attention has been given to within garden variation in species diversity, although Mendez et al. (2001) documented such variation as a result of micro-zonation in respect to crop composition and use. More attention has been given to between homegardens variations in diversity (Nair 2006; Peyre et al. 2006; Wiersum 2006). These studies illustrate that the species diversity is often not static, but changes in response to socio-economic dynamics. Consequently, homegardens should not be interpreted as a generic agroforestry system with uniform diversity characteristics, but rather as involving different types with specific features in respect to species diversity (Nair 2006; Wiersum 2006). Moreover, it is not only the species diversity per se that is important, but also the mix of different functional groups of crops in relation to the nutrition and cash needs of the households. For instance, Huang et al. (2002) identified three categories of functional groups in agroforestry systems, i.e. ecological, conservational and livelihood functional groups. The classified groups differ in their impact on ecological and socioeconomic sustainability respectively. Consequently, a prerequisite for obtaining a precise understanding of the relation between species diversity and homegarden sustainability, is that a better insight is obtained in the different dimensions of homegarden diversity at spatial and temporal scales and at the level of both species and functional groups. This paper documents the various dimensions of crop diversity in the homegardens of Sidama region of southern Ethiopia. The paper focuses specifically on the livelihood functional groups. This functional group classification can be hypothesized as being most amendable towards dynamic socio-economic conditions and was therefore selected as a good parameter for understanding the factors impacting on spatial and temporal variation in homegarden diversity. The original description of this functional group classification as given by Huang et al. (2002) was adapted by including not only food, cash and vegetable crops, but also fruit species.

The study was carried out in the south and southwestern highlands of Ethiopia where homegardening is widely practiced (Abebe 2005). The gardens are characterized by a unique combination of two dominant perennial crops: enset and coffee. Enset (Enset ventricosum (Welw.) Cheesman) is a herbaceous multipurpose crop, and a staple food for about 15 million people in the region. Food is extracted from its pseudostem and corm, and its by-products as well as other parts serve different purposes, such as fibre, wrapping material, fodder, shade and soil fertility maintenance. Coffee (Coffea arabica L.) is mainly used as cash crop, but also for household consumption. These two crops may be considered as keystone species in the system (Abebe et al. 2006). As an evergreen perennial crop, enset gives a permanent shade to understorey crops, including coffee. Soil management is facilitated by the use of enset residues as mulching material. Coffee is an ideal complimentary crop to enset. Not only is it architecturally and ecologically compatible with enset, but the harvest of both enset and coffee involves only selected plant parts. These ecologically compatible species do not only form the ecological matrix of the garden, but also allow combined production of both staple food for subsistence and a commercial good. Other components of these multispecies agroecosystems include root and tuber crops, fruits, vegetables, cereals, spices and other crops. Moreover, livestock is kept in the gardens and different tree species are grown to serve productive as well as protective functions; these homegarden components are not further considered in this paper.

In the Sidama region of south Ethiopia the ensetcoffee homegardens have been stable agricultural systems for centuries supporting populations that have densities of 360 up to 750 persons per square 
kilometres. They ensure food security in the areas, play a significant role in the regional and national economies, and also contribute to environmental resilience (ICRAF 1989; Asfaw and Woldu 1997; Kanshie 2002; Asfaw 2001; Abebe 2005). An interesting feature of the homegardens is that they are integral rather than complementary systems in the sense that they are not a component of a farming system in addition to open-field cultivation systems with stable food and/or commercial crops, but rather they are complete farming systems including both subsistence crops and commercial crops (Abebe et al. 2006). Such 'integral' homegardens are common in the East African highlands (Okigbo 1990). In contrast to the relatively small $(0.01-1 \mathrm{ha})$ 'complementary' homegarden systems they are of medium size (0.43 ha) (Abebe et al. 2006).

Although the enset-coffee homegardens in the Sidama region have high crop diversity, important variation between both crop composition and diversity is present at both spatial and temporal level. The paper addresses the following questions:

1. What are the various expressions of crop variety in the Sidamo enset-coffee homegardens in respect to overall crop diversity, within and between homegarden variation, and temporal variation?

2. How are the different expressions of biodiversity related to the sustainability and dynamics of the homegardens?

\section{Materials and methods}

The study area

The enset-coffee homegarden agroforestry systems are commonly practised in the Southern Nations, Nationalities and Peoples' Regional State (SNNPRS) of Ethiopia. The administrative zone of Sidama (Fig. 1) was selected for study as being representative with respect to the production systems as well as the prevailing population pressure in the highlands (Abebe 2005). Within Sidama several altitudinal zones are present ranging from 500 to $3,500 \mathrm{~m}$ a.s.l. The study was carried out in the moist (annual rainfall 1,000-1,600 $\mathrm{mm}$ ) and warm (mean annual temperature of $15-20^{\circ} \mathrm{C}$.) subtropical climatic zone

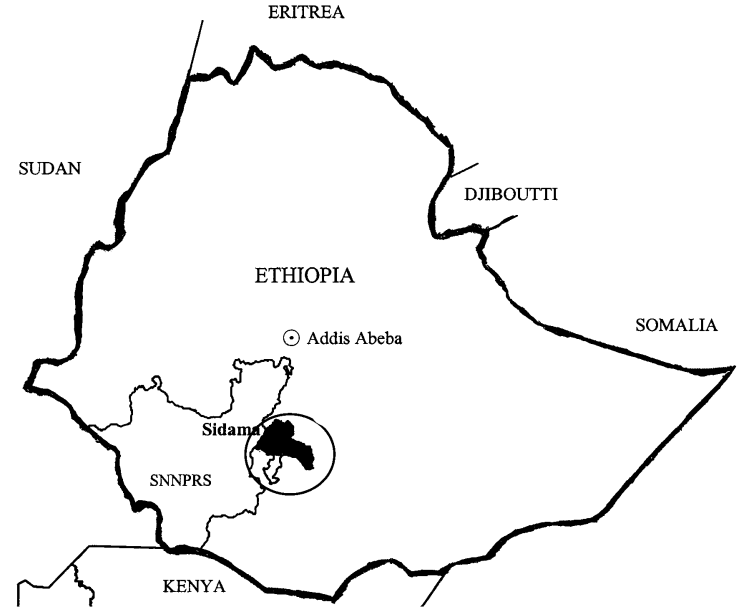

Fig. 1 Location of Sidama in Ethiopia

located at an altitude of 1,500-2,300 m. This agroecological zone, locally known as Gamoojje (Sidamigna) or Woyna Dega (Amharic), covers $54 \%$ of the land area and is the most important in terms of land productivity and prevalence of the homegardens. The study was undertaken in 12 Peasant Associations (PA, the lowest administrative unit in Ethiopia with about 400-800 inhabitants) selected from four Woredas (a district covering about 40-60 PAs) where these agroforestry systems are practised (Table 1). From each PA, 12 homegardens were selected on the basis of stratified random sampling amongst the three wealth categories poor, medium and rich categories of homegarden owners.

Methods of data collection

In the selected 144 homegardens detailed data were collected on the garden configuration and crop characteristics. The total area of the homegarden was measured and separate plots with specific species composition were identified and classified by dominant crop. For each plot, the area was measured, and the crop species composition was identified. Depending on the number and size of the different plots, and similarities of component species, within each plot quadrats of $50-500 \mathrm{~m}^{2}$ were laid out for detailed crop species inventory. The number of plants per species was measured by counting all perennial crops, and measuring species density of annual crops in sample plots in systematically selected $1 \times 1 \mathrm{~m}$ quadrats. 
Table 1 Geographical location and altitudinal ranges of sample Peasant Associations (PA's) in four Woredas in Sidama

\begin{tabular}{|c|c|c|c|c|c|c|}
\hline \multirow[t]{2}{*}{ No } & \multirow[t]{2}{*}{ Site (PA) } & \multirow[t]{2}{*}{ Woreda } & \multicolumn{2}{|c|}{ Locations of the PA offices } & \multirow[t]{2}{*}{ Altitude (m) } & \multirow[t]{2}{*}{ Dominant soil types } \\
\hline & & & Latitude & Longitude & & \\
\hline 1 & Setamo & Dara & $6^{\circ} 28^{\prime} 26.2^{\prime \prime} \mathrm{N}$ & $38^{\circ} 19^{\prime} 19.5^{\prime \prime} \mathrm{E}$ & $1,840-2,040$ & Eutric nitosols \\
\hline 2 & Shoyicho & Dara & $6^{\circ} 29^{\prime} 18.8^{\prime \prime} \mathrm{N}$ & $38^{\circ} 23^{\prime} 27.4^{\prime \prime} \mathrm{E}$ & $1,840-1,920$ & Eutric nitosols \\
\hline 3 & Qomato & Dara & $6^{\circ} 29^{\prime} 54.9^{\prime \prime} \mathrm{N}$ & $38^{\circ} 23^{\prime} 32.9^{\prime \prime} \mathrm{E}$ & $1,630-1,700$ & Eutric nitosols \\
\hline 4 & Belesto & Aleta Wondo & $6^{\circ} 36^{\prime} 03.5^{\prime \prime} \mathrm{N}$ & $38^{\circ} 24^{\prime} 33.1^{\prime \prime} \mathrm{E}$ & $1,910-2,000$ & Pellic vertisols \\
\hline 5 & Lela Honcho & Aleta Wondo & $6^{\circ} 30^{\prime} 37.0^{\prime \prime} \mathrm{N}$ & $38^{\circ} 23^{\prime} 20.1^{\prime \prime} \mathrm{E}$ & $1,740-1,820$ & Pellic vertisols \\
\hline 6 & Tesso & Aleta Wondo & $6^{\circ} 32^{\prime} 24.9^{\prime \prime} \mathrm{N}$ & $38^{\circ} 19^{\prime} 16.6^{\prime \prime} \mathrm{E}$ & $1,520-1,710$ & Eutric nitosols \\
\hline 7 & Sheyicha & Aleta Wondo & $6^{\circ} 37^{\prime} 08.8^{\prime \prime} \mathrm{N}$ & $38^{\circ} 25^{\prime} 06.6^{\prime \prime} \mathrm{E}$ & $1,910-1,970$ & Pellic vertisols \\
\hline 8 & Ferro 1 & Dale & $6^{\circ} 44^{\prime} 58.5^{\prime \prime} \mathrm{N}$ & $38^{\circ} 28^{\prime} 17.9^{\prime \prime} \mathrm{E}$ & $1,780-1,890$ & Orthic acrisols \\
\hline 9 & Ferro 2 & Dale & $6^{\circ} 44^{\prime} 25.9^{\prime \prime} \mathrm{N}$ & $38^{\circ} 29^{\prime} 52.3^{\prime \prime} \mathrm{E}$ & $1,860-1,940$ & Orthic acrisols \\
\hline 10 & Tula Aposto & Dale & $6^{\circ} 45^{\prime} 59.4^{\prime \prime} \mathrm{N}$ & $38^{\circ} 22^{\prime} 39.1^{\prime \prime} \mathrm{E}$ & $1,710-1,740$ & Chromic luvisols \\
\hline 11 & Chefasine & Awassa Zurya & $6^{\circ} 55^{\prime} 58.6^{\prime \prime} \mathrm{N}$ & $38^{\circ} 29^{\prime} 48.8^{\prime \prime} \mathrm{E}$ & $1,820-1,870$ & Eutric fluvisols \\
\hline 12 & Abela Tula & Awassa Zurya & $6^{\circ} 57^{\prime} 20.2^{\prime \prime} \mathrm{N}$ & $38^{\circ} 28^{\prime} 37.3^{\prime \prime} \mathrm{E}$ & $1,830-1,940$ & Eutric fluvisols \\
\hline
\end{tabular}

Note: The source for soil types is soil map of Sidama Zone Planning and Economic Development Department (SZPEDD). The other data are collected in the present study

These data were used to calculate diversity indices and area share of major crops.

Data analysis

Basic data were summarised as lists of crop species and their area share per plot and per farm. Each species was classified into a functional group in the form of a set of species with similar roles in the livelihoods of the local people. We distinguished ten functional groups (Appendix): root and tuber crops, vegetables, pulses, cereals, fruits, stimulants, spices and condiments, oil crops, medicinal plants, fragrance crops, and a rest group. To determine the diversity of crop species we calculated at both plot and garden level species richness, Shannon index and Evenness measure $(E)$. Shannon diversity index $\left(H^{\prime}\right)$ is calculated as $H \prime=-\sum p_{i} \ln p_{i}$ (Magurran 1988), where $p_{i}$ is the proportion of crop area composed of species $i$. The measure of evenness $(E)$ which is the ratio of observed diversity to maximum diversity is calculated as $E=H^{\prime} / H_{\max },=H^{\prime} /$ ln (Magurran 1988). The same was done for diversity of functional groups of crops. Differences in diversity between PA's were analysed using ANOVA. Variation in species composition among the different sites (PAs) was determined using Beta diversity, calculated as $\beta=1-C_{j}$, where $C_{j}$ is Jaccard's similarity index (Magurran 1988) $C_{j}=j /(a+b-j)$, where $j=$ the number of species shared by any two sites $a$ and $b, a=$ the number of species in site $a$, and $b=$ the number of species in site $b$. Different homegarden types were distinguished on the basis of the mean area share of the major crops (Abebe et al. 2006).

\section{Results}

Crop diversity at generic homegarden level

Within the 144 inventoried homegardens, a total number of 78 cultivated crop species were recorded. The key species enset and coffee were present in all gardens and an additional 11 species occurred in 50\% of the gardens. These consisted mainly of food crops such as maize, beans and cabbage that contribute to the daily diet of the farm family and are common in almost all farms. Other crops widely grown in the areas include avocado, banana, pumpkin, rhamnus and khat. Thirty-four species were rare, occurring in less than $5 \%$ of the farms (Appendix). The average number of crop species per farm was 16 ( \pm 3.9 SD) (Table 2).

A total of ten functional groups of crops were recognised, each represented by $3-15$ species. Out of the total of 78 crop species, most species were fruits (23.5\% of all species), followed by root and tubers (16.1\%) and vegetables (14.4\%). Other functional 
Table 2 Total and average number of crop species, mean values of Shannon $\left(H^{\prime}\right)$ and Evenness $(E)$ indices at the research sites (PAs)

\begin{tabular}{|c|c|c|c|c|c|c|c|c|c|c|}
\hline \multirow{2}{*}{$\begin{array}{l}\text { Site (PA) } \\
(n / \mathrm{PA}=12)\end{array}$} & \multirow[t]{2}{*}{ Woreda } & \multicolumn{3}{|c|}{ Number of crop species } & \multicolumn{2}{|c|}{ Shannon index } & \multicolumn{2}{|c|}{ Evenness index } & \multicolumn{2}{|c|}{ Functional groups of crops } \\
\hline & & Total & Mean & SD & $H^{\mathrm{i}}$ & SD & $E$ & SD & Mean & SD \\
\hline Setamo & Dara & 43 & $17.5^{\mathrm{ab}}$ & 3.2 & $1.50^{\mathrm{bc}}$ & 0.12 & $0.53^{\mathrm{bc}}$ & 0.05 & $8.58^{\mathrm{a}}$ & 0.90 \\
\hline Shoyicho & Dara & 44 & $17.7^{\mathrm{ab}}$ & 4.1 & $1.47^{\mathrm{bcd}}$ & 0.24 & $0.52^{\mathrm{bc}}$ & 0.11 & $8.08^{\mathrm{abc}}$ & 1.00 \\
\hline Qomato & Dara & 43 & $17.3^{\mathrm{b}}$ & 1.2 & $1.52^{\mathrm{b}}$ & 0.14 & $0.54^{\mathrm{b}}$ & 0.56 & $7.67^{\mathrm{bc}}$ & 1.15 \\
\hline Belesto & Aleta & 47 & $15.4^{\mathrm{bc}}$ & 3.7 & $1.32^{\mathrm{de}}$ & 0.19 & $0.49^{\mathrm{bc}}$ & 0.06 & $8.25^{\mathrm{ab}}$ & 0.97 \\
\hline Lela Honcho & Aleta & 48 & $15.8^{\mathrm{bc}}$ & 4.5 & $1.21^{\mathrm{e}}$ & 0.24 & $0.45^{\mathrm{c}}$ & 0.11 & $7.92^{\mathrm{abc}}$ & 0.90 \\
\hline Tesso & Aleta & 38 & $15.0^{\mathrm{bc}}$ & 3.1 & $1.75^{\mathrm{a}}$ & 0.12 & $0.65^{\mathrm{a}}$ & 0.06 & $8.08^{\mathrm{abc}}$ & 0.67 \\
\hline Sheyicha & Aleta & 43 & $15.6^{\mathrm{bc}}$ & 3.8 & $1.23^{\mathrm{e}}$ & 0.19 & $0.45^{\mathrm{c}}$ & 0.07 & $8.25^{\mathrm{ab}}$ & 1.14 \\
\hline Ferro 1 & Dale & 38 & $17.7^{\mathrm{ab}}$ & 2.5 & $1.53^{\mathrm{b}}$ & 0.14 & $0.54^{\mathrm{b}}$ & 0.07 & $8.58^{\mathrm{a}}$ & 1.08 \\
\hline Ferro 2 & Dale & 40 & $15.6^{\mathrm{bc}}$ & 3.0 & $1.34^{\mathrm{cde}}$ & 0.17 & $0.49^{\mathrm{bc}}$ & 0.07 & $8.17^{\mathrm{abc}}$ & 0.83 \\
\hline Tula Aposto & Dale & 43 & $20.3^{\mathrm{a}}$ & 3.5 & $1.64^{\mathrm{ab}}$ & 0.15 & $0.55^{\mathrm{b}}$ & 0.05 & $8.58^{\mathrm{a}}$ & 0.79 \\
\hline Chefasine & Awassa Z. & 27 & $13.0^{\mathrm{cd}}$ & 2.7 & $1.57^{\mathrm{b}}$ & 0.14 & $0.62^{\mathrm{a}}$ & 0.06 & $8.00^{\mathrm{abc}}$ & 0.60 \\
\hline Abela Tula & Awassa Z. & 26 & $11.7^{\mathrm{d}}$ & 2.1 & $1.27^{\mathrm{e}}$ & 0.36 & $0.53^{\mathrm{bc}}$ & 0.16 & $7.33^{\mathrm{c}}$ & 0.98 \\
\hline Mean (PA) & Awassa Z. & 40 & 16.0 & 3.9 & 1.45 & 0.25 & 0.53 & 0.09 & 8.13 & 0.97 \\
\hline Significance & & & $* *$ & & $* * *$ & & $* * *$ & & $*$ & \\
\hline
\end{tabular}

Note: Differences between sites are analysed using ANOVA, followed by Duncan's multiple range test. Means in a column followed by different letters indicate significant differences at $P<0.05$

$*$, **, and $* * *$ indicate significant differences at $P<0.05,<0.01$ and $<0.001$, respectively ( $F$ test)

groups included stimulant crops (10.0\%), cereals $(8.8 \%)$, pulses $(8.1 \%)$, spices and condiments $(4.5 \%)$, oil crops (3.2\%), medicinal and fragrance crops (2.9\%), and the rest group (8.6\%). On average 8.1 groups $( \pm 0.97 \mathrm{SD})$ were found in each garden. The minimum number of functional groups of crops per farm was 7.3 and the maximum was 8.6 showing that most of the groups are represented in the homegardens (Table 2). The data on the proportional share of the number of crop species in each functional groups does not have any relation with their abundance or garden cover. For instance, fruit crops constituted $23 \%$ of the number of crop species, but they covered only $2 \%$ of the farm area. On the other hand, coffee, only one of the stimulant crops, covered $33 \%$ of the farm area.

Nutritionally, the composition of crops widely produced and consumed in these systems is dominated by energy producing food crops (Table 3 ). The vitamin supply in the nutrition of the households is also expected to be sufficient, because vegetables such as cabbage are commonly present. Pulses and oil crops represent only $11 \%$ of the total number of species, but their area coverage and yield seems to be insufficient to fulfil nutritional requirements of many households. The shortage of protein-supplying crops such as beans especially in poor households, may cause deficiency in their diet. These data illustrate that not only species diversity per se, but also the function and quality of crops species needs consideration when relating species diversity to socioeconomic sustainability.

Spatial variation in diversity

\section{Differentiation in crop diversity within homegardens}

The homegardens often display a mosaic of patches or plots which are distinct from one another because of the dominant crop grown on it. For instance, one can recognize a coffee plot where the dominant crop is coffee but intercropped with other crops, or a maize plot which appears more like a monoculture with few or no associated crops. In total nine different plot types were distinguished dominated by specific crop species such as enset, coffee, maize, khat, sugarcane, sweet potato, pineapple or consisting of woodlots and grazing lands. These plot types are not equally rich in species (Fig. 2). The enset and coffee plots, with an 
Table 3 Common food crops, area of production and nutrient value

\begin{tabular}{llrlr}
\hline $\begin{array}{l}\text { Functional group } \\
\text { of crop }\end{array}$ & Main food crops & $\begin{array}{l}\text { Mean farm } \\
\text { area coverage }(\%)\end{array}$ & $\begin{array}{l}\text { Nutrient value per } 100 \text { g of edible } \\
\text { portions }\end{array}$ \\
\cline { 5 - 5 } & & & Calories & $\%$ Protein \\
\hline $\begin{array}{l}\text { Root and tuber } \\
\text { crops }\end{array}$ & Enset & 26.4 & 190 & 1.5 \\
& Sweet potato & 2.4 & 114 & 1.5 \\
Cereals & Yam & 0.8 & 41 & 1.0 \\
Vegetables & Maize & 17.0 & 363 & 10.0 \\
Fruits & Cabbage & 1.6 & 28 & 2.0 \\
& Avocado & 0.8 & 165 & 1.5 \\
Pulses & Banana & 0.6 & 116 & 1.0 \\
\hline
\end{tabular}

Note: The source for the nutrient value is World Food Program (1991)

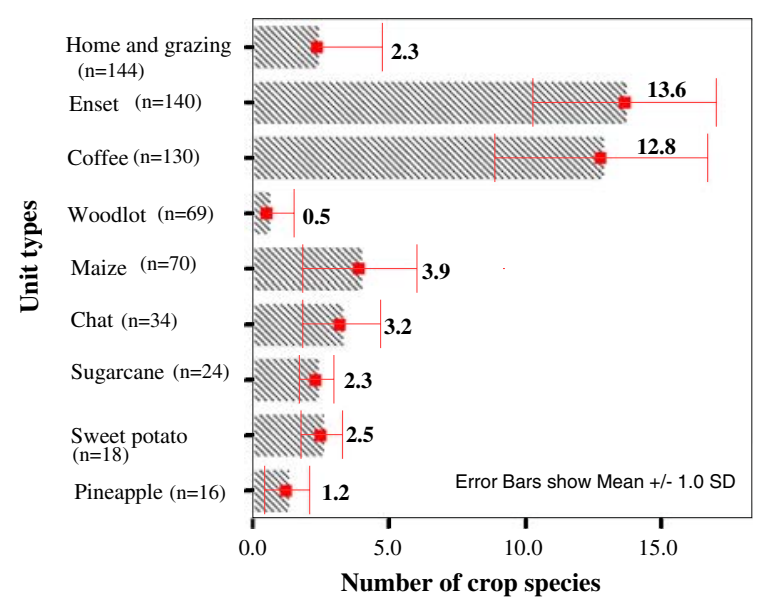

Fig. 2 Plot types and their average number of associated crop species. The number excludes the namegiving species ( $n=$ number of homegardens in which the plot type occurred)

average of 13.6 and 12.8 associated crops, respectively were the richest in species. Woodlots and pineapple plots are the poorest in species with 0.5 and 1.2 associated crop species, respectively.

\section{Differentiation in crop diversity between homegardens}

In addition to within-garden differentiation in species diversity, also between-homegarden differentiation in species diversity occurs. This differentiation is related to the importance of major crop species and to the presence of less-common or rare species. A major factor influencing such between-homegarden differentiation are regional differences in geographic conditions. The number of crop species significantly varied between sites (PAs) (ANOVA, $F=5.45$; $P<0.01$, Table 2). At PA level, the highest number of total species richness (48) was recorded at Lela Honcho while the lowest (26) was in Abela Tula. Farm level species richness was highest at Tula Aposto PA of Dale woreda where the mean of 20.3 species represented $47 \%$ of the total crops in the PA.

Not only species richness, but also the heterogeneity of crop species differed significantly across the PAs (Table 2). Species evenness varied with sites (ANOVA, $F=6.10 ; P<0.001$ ), the highest value being for farms in Tesso PA $(E=0.65)$, where new cash crops such as pineapple and khat have reduced the proportion of enset and coffee. Farms in Lela Honcho and Sheyicha PAs where coffee and enset shared about $80 \%$ of the crop area, showed the least uniform composition of crop species with evenness value of 0.45 . The evenness values are not very high indicating that in different homegardens crops are present in variable amounts. Enset $(26.4 \%)$ and coffee $(36.6 \%)$ accounted for a large share of the total area of crop production per farm (Fig. 3). The dominance of few crop species has therefore contributed to a low evenness value.

Sites were quite variable with respect to crop species composition, as shown by their dissimilarity values (Table 4). Chefasine is the outlying PA as it has the highest dissimilarity with all others. The closely located Belesto and Sheyicha PAs shared $73 \%$ of the crop species (dissimilarity value of 0.27 ). On the other hand, Shoyicho and Chefasine that are located about $65 \mathrm{~km}$ apart had a dissimilarity of 0.61 . Geographical distance partly explains the differences among the sites $\left(R^{2}=0.51\right.$, Fig. 4$)$. 


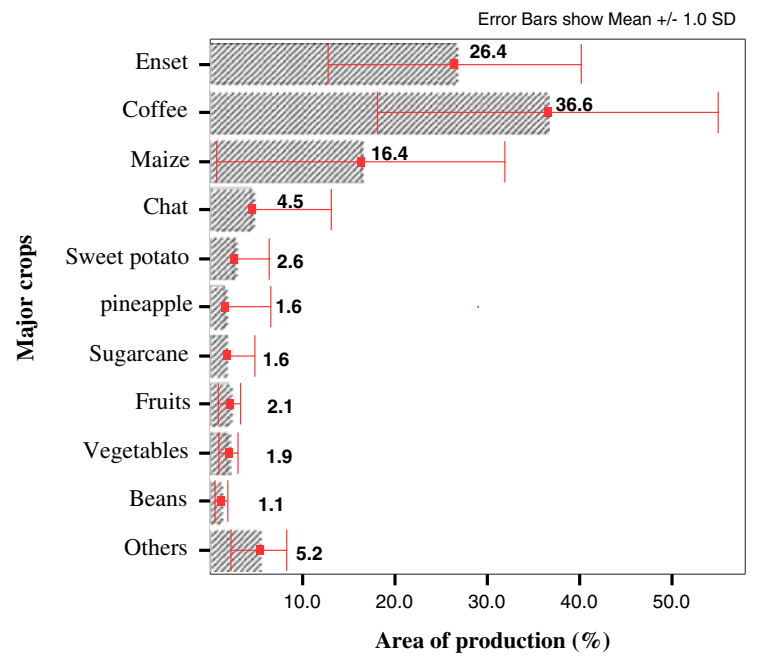

Fig. 3 Mean area share (in percentage of the farm area) of the major crops in farms. All 144 farms are used here. Error bars indicate one standard deviation

\section{Differentiation in homegarden types}

As a result of the important regional differentiation in homegarden composition and species composition, it was possible to distinguish various homegarden types. On the basis of the area covered by major crops in each site as well as the distribution of tree species (not further discussed in this paper) four distinct homegarden types were identified (Abebe et al. 2006) that differ in richness of plant species $(P<0.001)$ and in the area share of major crops (Table 5):

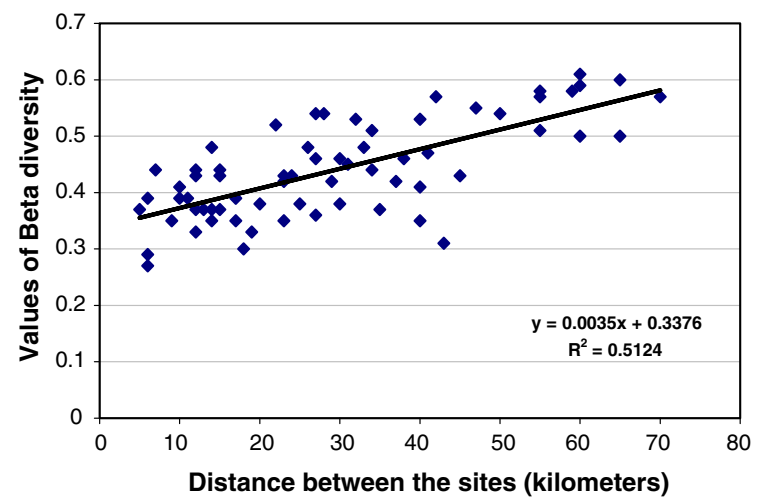

Fig. 4 The relationship between distance between the sites and their dissimilarity. Each dot represents the dissimilarity between two sites (PA's). See also Table 3

1. The enset-coffee-maize type. In a large part of the research area the homegardens belong to this type in which coffee and enset occupy ca. $75 \%$ of the farm land. In addition, maize is grown on ca. $10 \%$ of the land. Species diversity is relatively high: not only in respect to crop diversity but also in respect to associated tree species; in this garden type a mean of 41 cultivated crop and tree species are present. These homegardens are predominantly subsistence-oriented with enset and maize serving as main staple food crops and coffee serving as cash crop.

2. The enset-coffee-maize-sweet potato type is even more subsistence-oriented. The share of the staple crop enset is lower than the previous type,

Table 4 Levels of dissimilarity among sites in respect to composition of crop species

\begin{tabular}{|c|c|c|c|c|c|c|c|c|c|c|c|}
\hline Sites (PAs) & Shoyicho & Qomato & Belesto & $\begin{array}{l}\text { Lela } \\
\text { Honcho }\end{array}$ & Tesso & Sheyicha & Ferro 1 & Ferro 2 & Tula Aposto & Chefa-sine & $\begin{array}{l}\text { Abela } \\
\text { Tula }\end{array}$ \\
\hline Setamo & 0.29 & 0.35 & 0.30 & 0.37 & 0.35 & 0.35 & 0.35 & 0.37 & 0.31 & 0.60 & 0.50 \\
\hline Shoyicho & - & 0.33 & 0.37 & 0.44 & 0.39 & 0.39 & 0.48 & 0.42 & 0.42 & 0.61 & 0.57 \\
\hline Qomato & & - & 0.42 & 0.48 & 0.44 & 0.46 & 0.47 & 0.43 & 0.41 & 0.57 & 0.50 \\
\hline Belesto & & & - & 0.39 & 0.37 & 0.27 & 0.43 & 0.33 & 0.36 & 0.55 & 0.54 \\
\hline Lela Honcho & & & & - & 0.41 & 0.43 & 0.46 & 0.51 & 0.46 & 0.58 & 0.58 \\
\hline Tesso & & & & & - & 0.35 & 0.45 & 0.44 & 0.38 & 0.59 & 0.51 \\
\hline Sheyicha & & & & & & - & 0.38 & 0.37 & 0.38 & 0.57 & 0.53 \\
\hline Ferro 1 & & & & & & & - & 0.37 & 0.44 & 0.52 & 0.48 \\
\hline Ferro 2 & & & & & & & & - & 0.43 & 0.54 & 0.53 \\
\hline Tula Aposto & & & & & & & & & - & 0.54 & 0.43 \\
\hline Chefasine & & & & & & & & & & - & 0.39 \\
\hline
\end{tabular}

Note: The value of Beta diversity ranges from 0 tol. A dissimilarity value of 0 means the two sites are equal in composition of species, and 1 is when no species is shared among two sites 
Table 5 Area share (\%) of major crops in different homegarden types of Sidama

\begin{tabular}{|c|c|c|c|c|c|c|c|c|}
\hline \multirow{2}{*}{$\begin{array}{l}\text { Homegarden } \\
\text { type }(n)\end{array}$} & \multirow{2}{*}{$\begin{array}{l}\text { Mean no. of crop } \\
\text { and tree species } \\
\text { per farm }\end{array}$} & \multicolumn{7}{|c|}{ Area coverage of major crops $(\%)$} \\
\hline & & Enset & Coffee & Maize & Khat & $\begin{array}{l}\text { Sweet } \\
\text { potato }\end{array}$ & Pine apple & Others \\
\hline $\begin{array}{l}\text { 1. Enset-coffee- } \\
\text { maize ( } 84)\end{array}$ & $41 \pm 12.3 \mathrm{a}$ & $29.1 \pm 14.9$ & $46.5 \pm \_16.4$ & $10.5 \pm 6.5$ & $0.6 \pm 1.01$ & $1.2 \pm 2.0$ & $0.17 \pm 0.42$ & $12.2 \pm 3.1$ \\
\hline $\begin{array}{l}\text { 2. Enset-coffee- } \\
\text { maize-sweet } \\
\text { potato (12) }\end{array}$ & $43 \pm 11.3 \mathrm{a}$ & $17.2 \pm 8.8$ & $27.2 \pm 7.5$ & $33.0 \pm 6.4$ & $0.84 \pm 1.7$ & $10.6 \pm 5.7$ & 0 & $11.2 \pm 3.0$ \\
\hline $\begin{array}{l}\text { 3. Enset-coffee- } \\
\text { maize-khat } \\
(24)\end{array}$ & $25 \pm 5.6 \mathrm{~b}$ & $24.8 \pm 14.4$ & $13.7 \pm 11.8$ & $31.6 \pm 24.6$ & $19.8 \pm 12.8$ & $1.4 \pm 1.9$ & 0 & $8.7 \pm 1.54$ \\
\hline $\begin{array}{l}\text { 4. Enset-coffee- } \\
\text { maize- } \\
\text { pineapple } \\
\text { \& khat }(24)\end{array}$ & $30 \pm 7.9 \mathrm{~b}$ & $23.5 \pm 8.3$ & $31.1 \pm 8.0$ & $12.2 \pm 5.8$ & $6.5 \pm 8.7$ & $5.3 \pm 2.1$ & $8.5 \pm 8.8$ & $13.1 \pm 3.6$ \\
\hline Mean & $37 \pm 12.7$ & $26.4 \pm 13.9$ & $36.6 \pm 18.7$ & $16.4 \pm 14.9$ & $4.5 \pm 9.1$ & $2.6 \pm 3.8$ & $1.6 \pm 4.8$ & $11.9 \pm 3.1$ \\
\hline Significance & $* * *$ & $* *$ & $* * *$ & $* * *$ & $* * *$ & $* * *$ & $* * *$ & NS \\
\hline
\end{tabular}

Note: \pm indicate standard deviation of the mean. NS indicates non-significant differences while $*$, $* *$, and $* * *$ indicate significant differences at $P<0.05,<0.01$, and $<0.001$, respectively ( $F$ test). Different letters indicate significant differences between types

and farmers produce mainly maize and sweet potato as staple foods. The proportion of land devoted to coffee as a cash crop is much lower than in type 1 . Some farmers grow eucalyptus as an alternative cash crop. This homegarden type has the highest species richness of crops and trees, i.e. 43 species.

3. The enset-coffee-maize-khat type is much more cash oriented. Staple food is grown on $56 \%$ of the land and maize occupies more land than enset. Coffee is not abundant and khat has taken over the cash crop role. The diversity of plant species is low (25).

4. The enset-coffee-maize-khat-pineapple type accommodates a relatively balanced proportion of the different major crops. The staple food crops enset, maize and sweet potato occupy $41 \%$ of the land area while cash crops occupy $46 \%$. In addition to coffee and khat, pineapple is an important cash crop. Species diversity of this type is low, but higher than in type 3 .

Temporal variation in diversity

As demonstrated by the presence of different homegarden types differing in dominant crop species, in the Sidama region there is in some locations a tendency towards replacement of the traditional cash and or food crops by new cash or food crops. Such replacements often do not concern the total homegarden, but specific plots within the gardens. The internal differentiation of homegardens due to the emergence of localized new crop configurations is related to the gradual increase in importance of several crops, notably maize as an alternative to enset as a staple food crop, and khat and pineapple as alternative to coffee as a main cash crop. We observed the following trends in respect to food crop of maize and the cash crops khat and pineapple:

- Maize is the second important staple food crop in the research areas after enset. An advantage of maize over enset is that it is an annual instead of perennial food crop. Originally farmers cultivated it in scattered small open spaces as a supplement to enset production, but gradually cultivation is extended to larger plots. This trend is influenced by two main factors: (1) increasingly smaller land holdings force smallholders to focus more strongly on producing annual crops for immediate consumption; (2) agricultural extension practices promote maize as a priority crop to improve food self-sufficiency in the country. Farmers are advised to grow this crop on open fields to facilitate cultivation and improve efficiency of fertilizer use.

- Khat is the second important cash crop in the area after coffee. Its succulent and fresh leaves are 
chewed as stimulant. Over the last two decades, demand for khat has increased resulting in its increased cultivation at sites with easy road access to marketing centers. Such easy access to market is very important as khat should be delivered fresh to consumers. An advantage of khat over coffee as a cash crop is that it can be harvested many times a year; this results in a fair distribution of annual farm income. Many farmers also believe that it has a higher rate of return when compared to coffee and have increased the production of khat, largely at the expense of coffee. Such competition in land use between coffee and khat has been reported earlier for the eastern parts of the country (Getahun and Krikorian 1973). Khat can grow to a tree, but it is kept low and bushy through continuous leaf removal at harvesting. The bushy nature of its management limits combined cultivation with other crops. On the other hand, khat unlike maize, has a continuous ground cover throughout the year. Hence, from economic and ecological point of view, there are relatively few direct reasons to advise against this crop.

- Pineapple is the most recent cash crop introduction into the homegardens. The combination of climatic suitability and access to a good road infrastructure has motivated many farmers to grow pineapple as a cash crop. Traders from cities as far as Addis Ababa (350 km away) come with trucks to buy these fruits and retail them to cafes and restaurants for juice making. In some areas (Tesso PA) an average of $11.4 \%$ and a maximum of $32 \%$ of the homegarden area is cultivated with pineapple. In most cases, pineapple is grown in separate plots. However, the crop can also be grown in a systematic intercropping scheme with enset, coffee and other crops.

Thus, there is a tendency towards a growing importance of maize and sweet potato as alternative staple food crop replacing enset, and of khat and pineapple as alternative cash crops replacing coffee. The increased importance of these alternative crops is associated with a decline in the number of associated crops in these plots. This gradual development of monoculture plots within the integrated multistorey systems involves a negative overall trend in terms of crop diversity.

\section{Discussion}

Crop diversity and sustainability

In the present study, only deliberately planted and cultivated crop plants are considered. Ornamentals, auxiliary trees and weeds are not included. With a total of 78 cultivated crops species and an average of 16 crop species per homegarden, the Sidama ensetcoffee homegardens are clearly diverse. An additional 120 tree species were recorded in the gardens (Abebe 2005).

However, these data on overall species diversity and average species diversity per homegarden concern empirical data only, and cannot directly be related to the functioning of the homegardens. In order to assess the question of whether the homegardens can be considered to be sustainable, a more refined analysis of species diversity has to be made. As the present analysis was focused on crop species only, it should be considered as a first step in such a more refined analysis. Two major types of diversity were not yet incorporated in this study, i.e. diversity of tree species belonging to either the ecological and conservational functional groups as identified by Huang et al. (2002) as well as the genetic diversity in crop species. In respect to the first issue, as will be elaborated below, our study indicates that the distinction between these functional groups is not absolute, but species may have a multifunctional role. In respect to the second issue it can be noted that both coffee and enset display major genetic variety. A total of 42 landraces of enset were recorded in these homegardens out of which an average of six was grown in each farm. Likewise, 26 cultivars of coffee were identified, out of which 15 were local landraces and 11 were improved Coffee Berry Disease resistant varieties. An average of three coffee cultivars are grown in each farm.

But even when considering crop species only, our analysis illustrates the importance of not just relating sustainability to species diversity, but rather towards more specific features of species diversity. As discussed above, the functioning of the homegardens are highly related to the presence of the two keystone species enset and coffee which together account for $63 \%$ of the crop area. Enset forms a major staple food for the households, while coffee is the major cash crop providing income for household expenditures. Ecologically, both species can be grown in integration with 
each other and with other understorey as well as upperstorey crops, providing ecological services such as erosion control, provision of organic matter, and regulation of water and temperature. The multiple roles of both species in respect to the homegarden functioning illustrates that the distinction in specific groups of species having either a livelihood function, a ecological function and a conservation function should be considered as a first approximation only. This illustrates the relevance of relating homegarden functioning not just to species diversity, but towards more specific characteristics such as presence of keystone species with multifunctional characteristics, or presence of a well-balanced set of species with synergetic effects in respect either ecological or livelihood functions (Wiersum 2004). In respect to ecological sustainability not only overall species diversity has to be considered, but also the ecological complimentary between species. And in respect to socio-economic sustainability the complimentary in subsistence and cash crops should be considered, as well as further refinement of subsistence crops categories. From the utility point of view also the heterogeneity in functions matter. In order to fulfill the dietary and cash requirements of the households, food crops composed of carbohydrates, proteins, fat, vitamins, as well as cash crops should be fairly represented in the systems.

Variation and dynamics in crop diversity

Homegardens are often described as generic land-use systems with a high species diversity. However, as illustrated by our data, within and between these systems important variation in crop diversity may occur. This spatial variation is related to temporal variation in species diversity resulting from dynamics in crop composition. Two main processes of change in homegarden composition can be observed. At the one hand there is a tendency towards increased incorporation of cash crops as a result of adaptation to the expansion of commercial networks offering options for income generation. The advance of cash-cropping depends on both ecological factors such as crop suitability and socio-economic factors such as access to markets. At regional scale, important differences in these factors occur, and consequently gradually a geographic variation in homegarden type develops. At the other hand there is a tendency towards increased emphasis on annual food crops as a result of increasing fragmentation of land, affecting the area share of the major crops enset and coffee. Small farmers facing food shortage often reduce the area of enset production in favour of annual crops such as maize or sweet potato because they cannot wait for five or more years until enset reaches maturity. This process is primarily related to the financial status of individual households. Consequently, the trend in geographic specialization of homegarden composition as a result of increased commercialization is supplemented by a trend towards within-region differentiation in species composition due to increased socio-economic stratification and differentiation in land holdings. Similar trends in homegarden dynamics have also been reported in other regions. Several studies (Nair 2006; Peyre et al. 2006; Wiersum 2006; Scales and Marsden 2008) found that there is a tendency towards a gradual decrease in species diversity and structural simplification as a result of intensification of crop production. Such intensification is often related to the advent of commercialization. However, as indicated by our data, also the need to intensify staple food production may also result in such a biodiversity loss, as well as that crop intensification may only involve a specific portion of the garden. Moreover, some studies found that dualpurpose homegardens may have higher diversity than subsistence-only homegardens, and that remote homegardens can have lower biodiversity than those close to urban centers (Scales and Marsden 2008). This indicates that the advent of cash cropping does not always result in a loss of biodiversity. Rather, there exist multiple trajectories of change in homegarden biodiversity operating at different spatial scales.

\section{Conclusion}

In considering the role of species diversity on the ecological and socio-economic functioning and sustainability of homegardens it is important to differentiate between different dimensions of diversity. Three issues need attention. In the first place, species diversity should not just be considered as the number of species at aggregate (e.g. regional) level, but rather the specific features in respect of spatial and temporal variation in species diversity within and between homegardens should be considered. Secondly, it is important to consider not only species diversity but also diversity in functional groups. And thirdly, it is 
important to consider the presence of keystone species with multiple functional characteristics.

Acknowledgments The authors would like to thank the World Agroforestry Centre (ICRAF) for providing financial support to the field research.

Open Access This article is distributed under the terms of the Creative Commons Attribution Noncommercial License which permits any noncommercial use, distribution, and reproduction in any medium, provided the original author(s) and source are credited.

\section{Appendix}

See Table 6.

Table 6 List of crop species found in the agroforestry homegardens of Sidama and their frequency of occurrence

\begin{tabular}{|c|c|c|c|c|c|}
\hline \multirow[t]{2}{*}{ Scientific name } & \multirow[t]{2}{*}{ Family } & \multirow[t]{2}{*}{ English name } & \multicolumn{2}{|c|}{ Vernacular names } & \multirow{2}{*}{$\begin{array}{l}\text { Frequency } \\
(n / 144)\end{array}$} \\
\hline & & & Sidama & Amharic & \\
\hline \multicolumn{6}{|l|}{ Root and tuber crops } \\
\hline Enset ventricosum (Welw.) Cheesman & Musaceae & Enset, false banana & Wesse & Enset & 144 \\
\hline Dioscorea alata $\mathrm{L}$. & Dioscoriaceae & Yam & Bohe & Boyna & 85 \\
\hline Colocasia esculenta (L.) Schoot. & Araceae & Taro & Qolchoma & Godere & 73 \\
\hline Ipomea batatas (L.) Lam. & Convolvulaceae & Sweet potato & Metatesa & Sikuar dinich & 60 \\
\hline Manihot esculenta Cranz. & Euphorbiaceae & Cassava & Kassava & Kassava & 12 \\
\hline Solanum tuberosum $\mathrm{L}$. & Solanaceae & Potato & Dinich & Dinich & 9 \\
\hline Beta vulgaris L. & Chenopodiaceae & Beet root & Qey sir & Qey sir & 7 \\
\hline Daucus carota L. & Apiaceae & Carrot & Carota & Carot & 3 \\
\hline Dioscoria bulbifera L. & Dioscoriaceae & Aerial yam & Kotehare & & 1 \\
\hline \multicolumn{6}{|l|}{ Vegetables } \\
\hline Brassica integrifolia (West) O.E. schulz & Brassicaceae & Kale & Shana & Gomen & 143 \\
\hline Cucurbita pepo L. & Cucurbitaceae & Pumpkin & Baqula & Duba & 119 \\
\hline Capsicum frutescens $\mathrm{L}$. & Solanaceae & Hot pepper & Qarya & Qarya/Berbere & 62 \\
\hline Brassica oleracea $\mathrm{L}$. & Brassicaceae & Ethiopian kale & Bulo & Yegurage gomen & 48 \\
\hline Lycopersicon esculanta $\mathrm{L}$. & Solanaceae & Tomato & Timatim & Timatim & 23 \\
\hline Capsicum annuum $\mathrm{L}$. & Solanaceae & Chilly & Mitmitta & Mitmitta & 17 \\
\hline Solanum villosum $\mathrm{L}$. & Solanaceae & & Tunaye & & 13 \\
\hline Allium cepa $\mathrm{L}$. & Alliaceae & Shallot & Duma sunkurta & Qey shinkurt & 5 \\
\hline Brassica oleracea var. capitata & Brassicaceae & Cabbage & Tiqel Gomen & Tiqel gomen & 5 \\
\hline Lactuca sativa $\mathrm{L}$. & Asteraceae & Head lettuce & Selata & Selata & 3 \\
\hline Allium porrum $\mathrm{L}$. & Alliaceae & Leek & Baro & Baro & 3 \\
\hline Allium sativum $\mathrm{L}$. & Alliaceae & Garlic & Tuma & Nech shinkurt & 2 \\
\hline \multicolumn{6}{|l|}{ Pulses } \\
\hline Phaseolus vulgaris L. & Fabaceae & Common bean & Wahe & Adenguare & 143 \\
\hline Phaseolus lunatus L. & Fabaceae & Lima bean & Koyra & Adenguare & 43 \\
\hline Vicia faba L. & Fabaceae & Faba bean & & Baqela & 4 \\
\hline Pisum sativum L. & Fabaceae & Pea & & Ater & 3 \\
\hline Cajanus cajan (L). Mill. & Fabaceae & Pigeon pea & & Yewof ater & 3 \\
\hline \multicolumn{6}{|l|}{ Cereals } \\
\hline Zea mays L. & Poaceae & Maize & Bedela & Beqollo & 144 \\
\hline Sorghum bicolor (L.) Moench & Poaceae & Sorghum & Beshenqa & Mashilla & 44 \\
\hline Eragrostis tef (Zucc.) Trotter & Poaceae & Tef & Gashe & $\underline{T}$ ef & 9 \\
\hline Hordeum vulgare L. & Poaceae & Barely & Hayte & Gebs & 3 \\
\hline Triticum aestivum $\mathrm{L}$. & Poaceae & Wheat & Qemede & Sinde & 3 \\
\hline
\end{tabular}


Table 6 continued

\begin{tabular}{|c|c|c|c|c|c|}
\hline \multirow[t]{2}{*}{ Scientific name } & \multirow[t]{2}{*}{ Family } & \multirow[t]{2}{*}{ English name } & \multicolumn{2}{|c|}{ Vernacular names } & \multirow{2}{*}{$\begin{array}{l}\text { Frequency } \\
(n / 144)\end{array}$} \\
\hline & & & Sidama & Amharic & \\
\hline \multicolumn{6}{|l|}{ Fruits } \\
\hline Persea americana Mill. & Lauraceae & Avocado & Abukato & Abukato & 124 \\
\hline Musa paradisiaca $\mathrm{L}$. & Musaceae & Banana & Muze & Muz & 120 \\
\hline Psidium guajava L. & Myrtaceae & Guava & Saitonne & Zeitun & 62 \\
\hline Citrus sinensis (L.) Osbeck & Rutaceae & Sweet orange & Burtukanne & Bertukan & 54 \\
\hline Casimora edulis La Llave \& Lex. & Rutaceae & White sapota & Kasmire & Kazmir & 42 \\
\hline Ananas comosus (L.) Merr & Bromeliaceae & Pineapple & Ananas & Ananas & 34 \\
\hline Prunus persica (L.) Batsch & Rosaceae & Peach & Koke & Kok & 22 \\
\hline Carica papaya $\mathrm{L}$. & Caricaceae & Papaya & Papaye & Papaye & 22 \\
\hline Passiflora edulis Sims & Passifloraceae & Passion fruit & Hopi & Hopi & 19 \\
\hline Anona reticulata $\mathrm{L}$. & Annonaceae & Bullok's heart & Gishta & Gishta & 16 \\
\hline Mangifera indica $\mathrm{L}$. & Anacardiaceae & Mango & Mango & Mango & 12 \\
\hline Cyphomandra betacea (Cav.) Sendt. & Solanaceae & Tree tomato & Timatim Zaf & Timatim zaf & 11 \\
\hline Fragaria vesca $\mathrm{L}$. & Rosaceae & Strawberry & Enjori & Enjori & 7 \\
\hline Citrus aurantifolia (Christm) Swingle & Rutaceae & Lime & Lomi & Lomi & 6 \\
\hline Punica granatum $\mathrm{L}$. & Puniaceae & Pomgrante & Roman & Roman & 2 \\
\hline \multicolumn{6}{|l|}{ Stimulants } \\
\hline Coffea arabica $\mathrm{L}$ & Rubiaceae & Coffee & Buna & Buna & 144 \\
\hline Khata edulis (Vahl.) Forssk.ex Endl. & Celastraceae & Khat & Khat & Khat & 82 \\
\hline Nicotiana tobacum $\mathrm{L}$. & Solanaceae & Tobacco & Tembo & Tembaho & 12 \\
\hline \multicolumn{6}{|l|}{ Spices and condiments } \\
\hline Capsicum frutescens $\mathrm{L}$. & Solanaceae & Hot pepper & Qarya & Qarya/Berbere & 62 \\
\hline Ruta chalepensis $\mathrm{L}$. & Rutaceae & Rue & Senkurta & $\underline{T}$ Tenadam & 24 \\
\hline Capsicum aпnиит $\mathrm{L}$. & Solanaceae & Chilly & Mitmitta & Mitmitta & 17 \\
\hline Aframomum korarima (Braun) Jansen & Zingeberaceae & Falso cardamon & Korerima & Korerima & 9 \\
\hline Zingiber officinale L. & Zingeberaceae & Ginger & Janjibello & Zingibel & 5 \\
\hline Rosmarinus officinalis L. & Lamiaceae & Rose mary & Sega metbesha & Sega metbesha & 5 \\
\hline Ocimum basilicum $L$. & Lamiaceae & Sweet basil & & Besobela & 4 \\
\hline Lippia adonensis Hochst. Ex Walp. & Verbenaceae & & & Koseret & 4 \\
\hline Piper nigrum $\mathrm{L}$. & Piperaceae & Black pepper & & Qundo berbere & 1 \\
\hline Nigella sativa $\mathrm{L}$. & Ranunculaceae & Black pepper & & Tiqur azmud & 1 \\
\hline \multicolumn{6}{|l|}{ Oil crops } \\
\hline Ricinus communis L. & Euphorbiaceae & Castor & Qenboo & Gullo & 62 \\
\hline Brassica carinata A. Br. & Brassicaceae & Ethiopian mustard & & Gomen zer & 27 \\
\hline Arachis hypogea L. & Fabaceae & Ground nut & Ocholoni & Lewz/ocholoni & 13 \\
\hline Carthamus tinctorius L. & Asteraceae & Safflower & Suf & Suf & 4 \\
\hline Linum unisatissimum & Asteraceae & & Shalela & Telba & 1 \\
\hline \multicolumn{6}{|l|}{ Medicinal plants } \\
\hline Ocimum gratissimum $\mathrm{L}$. & Lamiaceae & & & Damakesse & 19 \\
\hline Foeniculum vulgare Mill. & Apiaceae & Fennel & & Inslal & 3 \\
\hline Otostegia integrrifolia Benth. & Lamiaceae & & & Tenjut & 2 \\
\hline Artemisia absinthium L. & Asteraceae & & & Ariti & 1 \\
\hline
\end{tabular}


Table 6 continued

\begin{tabular}{|c|c|c|c|c|c|}
\hline \multirow[t]{2}{*}{ Scientific name } & \multirow[t]{2}{*}{ Family } & \multirow[t]{2}{*}{ English name } & \multicolumn{2}{|c|}{ Vernacular names } & \multirow{2}{*}{$\begin{array}{l}\text { Frequency } \\
(n / 144)\end{array}$} \\
\hline & & & Sidama & Amharic & \\
\hline \multicolumn{6}{|l|}{ Fragrance plants } \\
\hline Ocimum gratissimum $\mathrm{L}$ & Lamiaceae & & & Damakesse & 19 \\
\hline Lippia adoensis Hochst. Ex Walp & Verbanaceae & & & Kesse & 17 \\
\hline Cymbopogon citratus (DC.) Stapf. & Poaceae & Lemon grass & & Tej-sar & 2 \\
\hline \multicolumn{6}{|l|}{ Other crops } \\
\hline Rhamnus prinoides L' herit & Rhamnaceae & Rhamnus & Taddo & Gesho & 101 \\
\hline Saccharum officinarum L. & Poaceae & Sugarcane & Shenkora & Shenkorageda & 78 \\
\hline Lagenaria siceraria (Mol.) Stardl. & Cucurbitaceae & Bottle gourd & & Qil & 7 \\
\hline Agave sisalana Perrine ex. Engelm.. & Amaryllydaceae & Sisal & Qacha & Qacha & 6 \\
\hline Gossypium herbaceum $\mathrm{L}$. & Malvaceae & Cotton & & Tit & 3 \\
\hline Sorghum dochna (Forsk.) Snowden & Poaceae & Sweet stalk sorghum & & Tinqish & 1 \\
\hline Pennisetum purpureum Schumach & Paniaceae & Elephant grass & & Zihone sar & 17 \\
\hline Chloris gayana Kunth & Paniceae & Rhodes grass & Rodes & Rodes & 3 \\
\hline Desmodium unicinatum (Jacq.) DC & Leguminoseae & Desmodium & & & 1 \\
\hline
\end{tabular}

The species are listed according to the functional group they belong to

\section{References}

Abebe T (2005) Diversity in homegarden agroforestry systems of southern Ethiopia. Dissertation, Wageningen University, The Netherlands

Abebe T, Wiersum KF, Bongers F, Sterck FJ (2006) Diversity and dynamics in homegardens of southern Ethiopia. In: Kumar BM, Nair PKR (eds) Tropical homegardens: timetested example of sustainable agroforestry. Springer, Dordrecht, pp 123-142

Asfaw Z (2001) Origin and evolution of rural homegardens in Ethiopia. In: Friis I, Ryding O (eds) Biodiversity research in the Horn of Africa. Proceedings of the 3rd International Symposium on the Flora of Ethiopia and Eritrea at the Carlsberg Academy, Copenhagen, August 25-27, 1999. Biologiske Skrifter 54, pp 273-286

Asfaw Z, Woldu Z (1997) Crop associations of homegardens in Welayita and Gurage in southern Ethiopia. SINET: Ethiop J Sci 20:73-90

Fernandes ECM, Nair PKR (1986) An evaluation of the structure and function of tropical homegardens. Agric Syst 21:279-310

Getahun A, Krikorian AD (1973) Khat: coffee's rival from Harar, Ethiopia. I. Botany, cultivation and use. Econ Bot 27:353-377

Huang W, Luukkanen O, Johanson S et al (2002) Agroforestry for biodiversity conservation of natural reserves: functional group identification and analysis. Agrofor Syst 55:65-72

Huston MA (1994) Biological diversity: the coexistence of species on changing landscapes. Cambridge University Press, Cambridge
ICRAF (1989) Agroforestry potentials for the Ethiopian Highlands. Working paper no. 21, International Centre for research in Agroforestry (ICRAF), Nairobi, Kenya

Kanshie TK (2002) 5,000 years of sustainability? A case study on Gedeo landuse. PhD Dissertation, Wageningen University, The Netherlands

Kumar BM, Nair PKR (2004) The enigma of tropical homegardens. Agrofor Syst 61:35-152

Kumar BM, Nair PKR (eds) (2006) Tropical homegardens. A time-tested example of sustainable agroforestry, Advances in Agroforestry, vol 3. Springer, Dordrecht

Magurran AE (1988) Ecological diversity and its measurement. Croom Helm, London

Mendez VE, Lok R, Somarriba E (2001) Interdisciplinary analysis of homegardens in Nicaragua: micro-zonation, plant use and socioeconomic importance. Agrofor Syst 51(2):85-96

Nair PKR (2006) Whither homegardens? In: Kumar BM, Nair PKR (eds) Tropical homegardens: a time-tested example of sustainable agroforestry. Springer, Dordrecht, pp 355-370

Okigbo BN (1990) Homegardens in tropical Africa. In: Landauer K, Brazil M (eds) Tropical homegardens. Selected papers from an International workshop held at the Institute of Ecology, Padjadjaran University, Bandung, Indonesia, 2-9 December 1985. United Nations University Press

Peyre A, Guidal A, Wiersum KF, Bongers F (2006) Homegarden dynamics in Kerala, India. In: Kumar BM, Nair PKR (eds) Tropical homegardens: a time-tested example of sustainable agroforestry. Springer, Dordrecht, pp 87-103

Scales BR, Marsden SJ (2008) Biodiversity in small-scale tropical agroforests: a review of species richness and 
abundance shifts and the factors influencing them. Environmental Conservation 35(2):160-172

Torquebiau E (1992) Are tropical homegardens sustainable? Agric Ecosyst Environ 41:189-207

Wiersum KF (2004) Forest gardens as an 'intermediate' landuse system in the nature-culture continuum: characteristics and future potential. Agrofor Syst 61:123-134
Wiersum KF (2006) Diversity and change in homegarden cultivation in Indonesia. In: Kumar BM, Nair PKR (eds) Tropical homegardens: a time-tested example of sustainable agroforestry. Springer, Dordrecht, pp 13-24

World Food Program (WFP) (1991) Manual on food nutritional status. WFP, Rome 